\title{
Proliferative enteropathy (Lawsonia intracellularis) outbreak in rabbits in Brazil ${ }^{1}$
}

\author{
Paulo V. Peixoto ${ }^{2 \star}$, Ticiana N. França ${ }^{3,4}$, Carlos T. Ribeiro ${ }^{5}$, Pedro \\ S. Bezerra Jr6 and David Driemeier ${ }^{7}$
}

\begin{abstract}
Peixoto P.V., Ribeiro C.T., Bezerra Jr P.S., Driemeier D. \& França T.N. 2008. Proliferative enteropathy (Lawsonia intracellularis) outbreak in rabbits in Brazil. Pesquisa Veterinária Brasileira 28(10):447-451. Departamento de Nutrição Animal e Pastagem, Instituto de Zootecnia, Universidade Federal Rural do Rio de Janeiro, Seropédica, RJ 23890-000, Brazil. E-mail: pfpeixoto@terra.com.br

An outbreak of Lawsonia intracellularis infection in rabbits, which occurred in 1988 in Rio de Janeiro state, Brazil, is reported. The disease had an acute course (24-48 hours) with clinical signs characterized by brownish or green diarrhea and dehydration. Occasionally, the animals died one day after the onset of diarrhea, without showing any other clinical signs. At necropsy, the ileum was prominent, firm and had a thickened wall; it was dilated in the caudal direction and had a somewhat reticulated appearance, perceptible through the serosa. The thickened mucous membrane had finely corrugated aspect and a shiny surface. The ileocecal valve and surrounding areas were slightly edematous and irregular. The Peyer's patches were sometimes more evident. There was moderate enlargement of the mesenteric lymph nodes. The histological examination revealed different degrees of hyperplasia of the epithelial cells of intestinal crypts consisting of poorly differentiated, hyperchromatic cells with high mitotic index, arranged in a pseudostratified layer which, in some cases, reached the apical portions of the villi. The inflammatory infiltrate between the hyperplastic epithelial cells was composed of lymphocytes, plasma cells, macrophages, some eosinophils and globular leukocytes. Silver impregnation revealed large numbers of bacteria with morphology of the genus Lawsonia in the apical pole of cryptal enterocytes. These bacteria reacted positively to a Lawsonia intracellularis polyclonal antibody by the avidin-biotin immunohistochemistry method.
\end{abstract}

INDEX TERMS: Lawsonia intracellularis, proliferative enteropathy, rabbits, Brazil.

\footnotetext{
${ }^{1}$ Received on January 30, 2008.

Accepted for publication on April 7, 2008.

2 Depto Nutrição Animal e Pastangem, Instituto de Zootecnia, Universidade Federal Rural do Rio de Janeiro (UFRRJ), Seropédica, RJ 23890000, Brazil. *Corresponding author: pfpeixoto@terra.com.br

${ }^{3}$ Centro de Ciências Biológicas e da Saúde, Faculdade de Medicina Veterinária, Universidade Estácio de Sá, Rio de Janeiro, RJ 22783320, Brazil.

${ }^{4}$ Universidade Federal do Rio de Janeiro, Faculdade de Medicina, Depto Cirurgia, Centro de Cirurgia Experimental, Bloco J, $2^{\circ}$ andar, Ilhado Fundão, Rio de Janeiro, RJ 21944-970.

${ }^{5}$ Mestrado em Ciências Veterinárias, UFRRJ, Seropédica, RJ.

${ }^{6}$ Depto Medicina Veterinária, Universidade Federal de Lavras (UFLA), Campus Universitário, Cx. Postal 37, Lavras, MG 37200-000, Brazil.

7 Depto Patologia Clínica Veterinária, Universidade Federal do Rio Grande do Sul (UFRGS), Av. Bento Gonçalves 9090, Porto Alegre, RS 91540-000, Brazil.
}

RESUMO.- [Surto de Enteropatia Proliferativa (Lawsonia intracellularis) em coelhos no Brasil.] Descreve-se um surto de infecção por Lawsonia intracellularis em coelhos em Mendes, Estado do Rio de Janeiro. A doença manifestou-se, de forma aguda (24-48 horas), com sintomatologia caracterizada por diarréia marrom ou esverdeada, e desidratação. Ocasionalmente, os animais morriam um dia após o início da diarréia, sem apresentar outros sintomas. À necropsia verificou-se íleo proeminente, firme, com parede muito espessada, progressivamente dilatado no sentido caudal e com aspecto algo reticulado perceptível através da serosa. A mucosa espessada tinha aspecto finamente corrugado e superfície brilhante. A válvula íleo-cecal e imediações do ceco encontravam-se um pouco edemaciadas e irregulares. Por vezes, as placas de Peyer estavam mais 
evidentes. Observou-se também moderado aumento de volume dos linfonodos mesentéricos. O exame histológico revelou diferentes graus de hiperplasia das células epiteliais das criptas intestinais (células pouco diferenciadas, hipercromáticas, arranjadas de forma pseudo-estratificada e com alto índice mitótico) que, em parte dos casos, atingia a porção apical das vilosidades. A infiltração inflamatória, entre as células epiteliais hiperplásicas, era composta por linfócitos, plasmócitos, macrófagos, alguns eosinófilos e leucócitos globulóides. A impregnação por prata revelou grande número de bactérias com morfologia compatível com às do gênero Lawsonia no pólo apical dos enterócitos das criptas. Essas bactérias reagiram positivamente ao anticorpo policlonal para Lawsonia intracellularis pelo método imunohistoquímico de avidina biotina.

TERMOS DE INDEXAÇÃO: Lawsonia intracellularis, enteropatia proliferativa, coelhos, Brasil.

\section{INTRODUCTION}

Porcine Proliferative Enteropathy (PPE) or Porcine Intestinal Adenomatosis Complex (PIAC) comprehends various clinical-pathological conditions associated with infection by Lawsonia intracellularis (LI) (McOrist et al. 1995). The lesions caused by the agent are concentrated in the intestine, especially in the ileum. In general, PPE is considered a silent illness, although it is associated with significant economic losses (intermittent diarrheic processes, decrease in feed conversion capacity, and decline in conception rates).

Li has also been diagnosed in horses (Cooper et al. 1997, Wuersch et al. 2006), mice (Go et al. 2005), hamsters (Cooper et al. 1997), wild boars (Jacobson et al. 2005), foxes, wolves, red deer (Tomatová et al. 2003), ostriches (Cooper et al. 1997) and emus (Lemarchand et al. 1997).

Studies describing this bacterium in rabbits are scarce; in addition to the 1988 outbreak reported here, there is only one account of $\mathrm{Li}$ occurrence in rabbits in Brazil (Sonne et al. 2003).

In rabbits, as well as in other species but swine, the epidemiology and clinic and pathological pictures of Proliferative Enteropathy (PE) remain unclear given its low occurrence. Several early reports have described the presence of bacteria in the apical pole of rabbit enterocytes; however, that condition was still referred to as Histiocytic Enteritis or acute typhlitis due to an acute intracellular Vibrio infection (Moon et al. 1974, Umemura et al. 1982, Hotchkiss et al. 1996).

The clinical signs are unspecific; the animals can remain asymptomatic (Duhamel et al. 1998) or exhibit diarrhea alone (Duhamel et al. 1998, Schauer et al. 1998), which makes the clinical diagnosis of the disease difficult in farms (Duhamel et al. 1998).

Diarrhea, apathy, dehydration and death of the animals, with an evolution time of approximately 40 days, have been observed (Sonne et al. 2003). More severe clinical pictures with high morbidity and mortality rates, considered atypical, have been described by Schauer et al. (1998) for rabbits aging from two to four months. In that case, however, there was coinfection with $\mathrm{Li}$ and enteropathogenic Escherichia coli.
Regarding macroscopic alterations, only thickening of ileum and colon walls (Duhamel et al. 1998, Schauer et al. 1998, Watarai et al. 2004) and lymphadenomegaly (Duhamel et al. 1998, Schauer et al. 1998) have been described. Microscopically, large $L i$ aggregates initially infecting the villi in a very characteristic way, and later affecting the crypts, can be observed. In addition, a marked thickening of the ileal mucous membrane, characterized by the presence of elongated, voluminous, hyperchromatic enterocytes arranged in a pseudostratified form, has been reported. The marked crypt proliferation alters the ratio between villi and crypts from 3:1 to 1:1 (Duhamel et al. 1998). Additionally, Schauer et al. (1998) reported a decrease in the amount of goblet cells, and the presence of argyrophilic bacteria in the apical pole of enterocytes.

The aim of this study was to describe the clinic and pathological aspects of a PE outbreak in rabbits that occurred in Rio de Janeiro state in 1988.

\section{MATERIALS AND METHODS}

Twenty-five rabbits of both sexes from a farm in Mendes County, Rio de Janeiro state, with ages between 45 and 80 days, were referred to SAP-PSA, Convênio UFRRJ/Embrapa, for anatomicalpathological diagnosis from 1988 to 1989 . All the rabbits were necropsied. Fragments from different organs, especially those bearing alterations, were sectioned into representative portions with a maximum thickness of $0.5 \mathrm{~cm}$ and fixed in $10 \%$ formalin. After fixation, the fragments were dehydrated in absolute ethyl alcohol, treated with xylol and embedded in paraffin. The blocks were sectioned at 5 micrometers, and stained with Hematoxylin and Eosin (HE) for subsequent analyses. The special WarthinStarry staining was also employed. Intestine and lymph node samples were subjected to immunohistochemistry (Guedes et al. 2002) using a polyclonal anti- $L i$ antibody diluted 1:15.000, which was detected by the avidin-biotin method. The immunohistochemistry protocol included: (1) quenching of endogenous peroxidase activity by incubation of the slides in methanol containing $3 \% \mathrm{H} 2 \mathrm{O} 2$ for 15 minutes, (2) previous digestion of the sections attached to slides with $0.1 \%$ trypsin for 15 minutes at $37^{\circ} \mathrm{C}$, (3) microwave irradiation of the slides immersed in $100 \mathrm{ml}$ citrate buffer at $\mathrm{pH} 6$ for 2 minutes at maximal power, reaching $60^{\circ} \mathrm{C}$, (4) blocking by incubation with $5 \%$ non-fat powdered milk for 20 minutes, (5) incubation with the primary polyclonal anti- $\mathrm{Li}$ antibody for 45 minutes at $37^{\circ} \mathrm{C},(6)$ washing with PBS and (7) incubation with avidin-biotin-peroxidase complex (ABC) for 40 minutes at room temperature. The reaction was developed using diaminobenzidine (DAB) as chromogen. Fragments of intestine and the intestinal contents of 5 rabbits were inoculated and incubated for 96 hours. Samples were inoculated in Petri plates containing brain-heart broth, agar, blood and antibiotics (15 units/ $\mathrm{ml}$ bacitracine, 5 units $/ \mathrm{ml}$ novobiocin, and 1 unit $/ \mathrm{ml}$ polymyxine sulfate), and were incubated at $36^{\circ} \mathrm{C}$ for 96 hours in a microaerophilic atmosphere generated with a mixture of $10.0 \%$ $\mathrm{CO}_{2}, 5.0 \% \mathrm{O}_{2}$, and $85.0 \% \mathrm{~N}_{2}$. Various liquid (Brucella broth, trypticase broth), semi-solid (thiol or thioglycollate in $0.3 \%$ agar) and solid (thiol or trypticase in $0.5 \%$ agar) culture media were used, in tubes or plates, aiming for the final isolation of the agent.

\section{RESULTS}

Epidemiology. The observation of the disease in rabbits in Rio de Janeiro state was performed in October of 1988 
on a farm located in the municipality of Mendes. The farm's livestock comprised approximately 1,000 rabbits, 200 of which were breeding stock. The disorder affected one to four animals per day (for some times, up to nine rabbits were affected), and showed an evolution time of 24-48 hours. The animals, especially those between 45 and 80 days of age, exhibited apathy, emaciation and diarrhea with dark and fetid feces. Subsequently, the disease started affecting the animals shortly before weaning. There was significant improvement with the adoption of basic prophylactic procedures. The presence of coccidia (Eimeria spp.) in the feces was also detected. Sulfa treatment was started, and an improvement of the clinical picture could be observed after that; however, such an improvement could be attributable to hygiene measures too.

Clinical and pathological features. The disease manifested in an acute form (24-48 hours) with symptoms characterized by dehydration and fetid diarrhea, with feces varying from totally liquid (aqueous) to a more consistent form that displayed a dark, chocolate or moss green color. Occasionally, the animals died one day after the onset of diarrhea without any other symptoms. Macroscopically, the ileum was very prominent, firm, with a very much thickened wall (Fig.1), and progressively dilated in the caudal direction. When observed through the serosa, this organ exhibited a somewhat reticulated aspect, or displayed transversal folds. The thickened mucous membrane had a finely corrugated appearance (Fig.1) and a shiny surface; rarely, small ulcerations were present. The ileocecal valve and surrounding areas were slightly enlarged, somewhat edematous and irregular. The contents of the small intestine were scarce; their consistency varied from aqueous to mucous, and their color was greenish, close to the normal, or reddish-chocolate in some cases. The Peyer's patches were sometimes elevated, more evident than usual. The

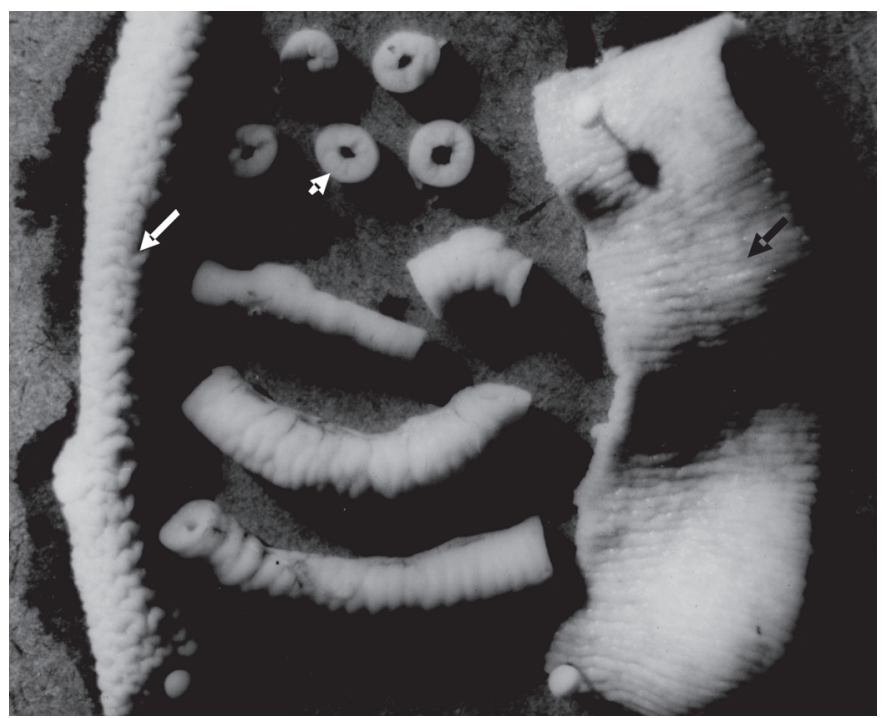

Fig.1. Thickening of the ileal wall (small arrow); open segments of the ileum with a finely corrugated aspect (black arrow) and reticulated aspect (white arrow). contents of the large intestine were usually less consistent than normal. Hyperemia and slight thickening of the duodenum and jejunum were also observed. A moderate enlargement of the mesenteric lymph nodes was also noticeable. Microscopically, the lesions in the ileum corresponded to different degrees of hyperplasia of the epithelial cells in the crypts, which were usually composed of fairly undifferentiated, cells with very hyperchromatic nuclei, arranged in a pseudostratified way (Fig.2-4). These proliferative cells would frequently extend up to the apexes of the villi (Fig.3). Mitotic figures were generally very numerous. In part of the rabbits only a few or none goblet cells were observed. The inflammatory infiltration between the hyperplastic epithelial cells was composed mainly of lymphocytes, plasma cells, some eosinophils and globular leukocytes and, sometimes, macrophages. Additionally, secondary bacterial infection, ulcerations and mild hemorrhages were sometimes found. Lymphoid hyperplasia in

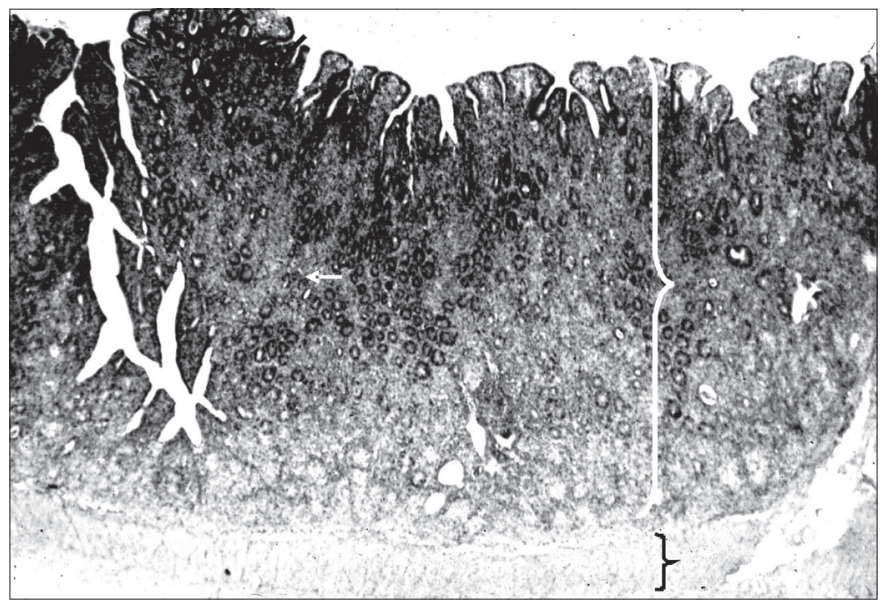

Fig.2. Thickened ileal mucous membrane due to cryptal cell hyperplasia and inflammation (white curly brace); part of the muscularis mucosae (black curly brace). HE, obj.4x.

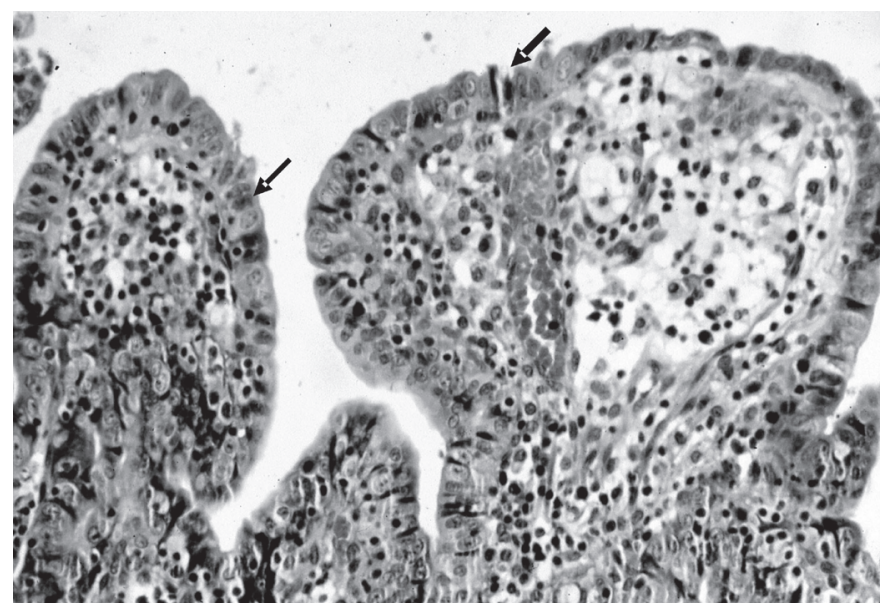

Fig.3. Poorly differentiated epithelial cells (arrows) overlaying the apexes of flattened ileal villi; mixed inflammation in the submucosa. HE, obj.16x. 
mesenteric lymph nodes was also observed. Silver staining (Warthin-Starry) revealed the presence of argyrophilic bacteria in the apical pole of enterocytes of the ileal crypts.

Bacteriological tests. The microscopical examination (phase contrast and dark field) performed on the small and large intestine contents revealed the presence of numerous rods with morphological and motile characteristics of bacteria belonging, at the time of this study, to the genus Campylobacter, in addition to motile and non-motile cocci. Small, convex, shiny, grayish-white non-hemolytic colonies measuring around $1 \mathrm{~mm}$ in diameter developed in the inoculated dishes. The microscopical examination of the bacteria revealed the presence of comma-, gull wing- and S-shaped Gram-negative rods, characteristic of the bacterial genus mentioned above and referred to as Lawsonia today, in addition to some motile and non-motile cocci. The attempts to isolate the agent for biochemical characterization at this time were unsuccessful.

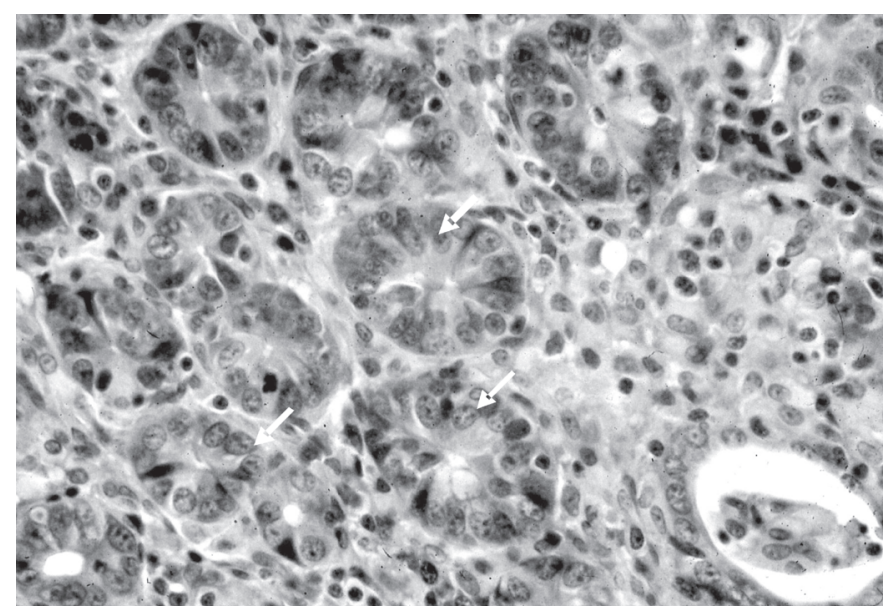

Fig.4. Poorly differentiated epithelial cells (arrows) in hyperplastic ileal crypts of the mide portion of the mucosa; absence of goblet cells. HE, obj.40x.

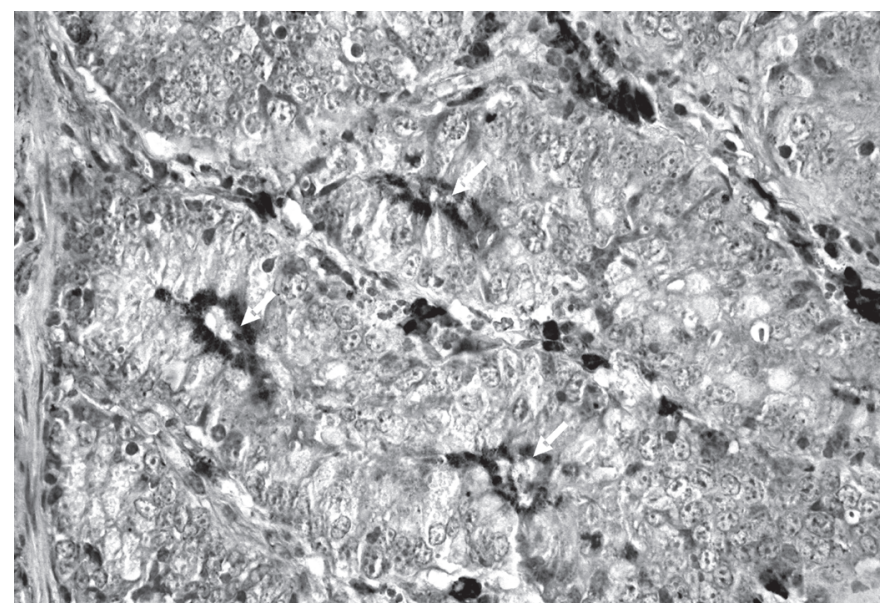

Fig.5. Lawsonia intracelullaris in ileal cryptal epithelial cells (arrows) and in macrophages, detected by Lawsonia intracellularis polyclonal antibody by the avidin-biotin immunohistochemistry method. Obj.40x.
Immunohistochemistry. The anti-Lipolyclonal antibody reacted positively with the epithelia of intestinal crypts (Fig.5), villi and Peyer's patches of the ilea.

\section{DISCUSSION}

The diagnosis of PE in association with Lawsonia intracellularis $(L I)$ in rabbits was based on the characteristic clinic and pathological aspects of this disease, and was confirmed by the histochemical and immunohistological demonstration of $L i$ in the intestines of the necropsied rabbits. The bacteriological tests were also compatible with the diagnosis.

Hygienic conditions described as inadequate by several authors (McOrist et al. 1993, Pearce 1997, Stege et al. 2000, Boesen et al. 2004), were detected, and could be related to the onset of the outbreaks. More recently, the agent Li has been antigenically demonstrated to be the same independently of the affected species (Smith \& Lawson 2001). In considering rabbits, the infection can arise from contact with wastes or materials from swine farms (Driemeier 2007, unpublished data). In this study, it was not possible to establish if the disease in rabbits originated from contact with substances arising from swine.

The disease had an acute course and would sometimes lead to death in less than 24 hours after the onset of the symptoms, which usually comprised only nonhemorrhagic diarrhea and apathy; however, in most of the cases the evolution was acute.

The remarkable mortality observed in rabbits is atypical as compared with other reports on the disease in association with $L i$ infection in this species (Duhamel et al. 1998, Watarai et al. 2004). On the other hand, the mortality rate during the outbreak that affected lagomorphs (rabbits and chinchillas) in Rio Grande do Sul state was $62 \%$ (Sonne et al. 2003).

The very bad hygienic conditions and the coinfection by Eimeria are important factors that must also be taken into account. The association of $L i$ with several pathological agents is related to atypical morbidity and mortality rates in rabbits (Schauer et al. 1998) and swine (Jacobson et al. 2005). Six out of the 25 animals examined were coinfected with the coccid. Since the lesions found were not severe, and both pathological processes regressed with the improvement of the management conditions and the use of sulfa treatment, which targeted coccidiosis, determining if the observed virulence in these cases $(24 \%)$ was due to the coinfection only, to the bad management conditions alone, or to the combination of both factors, was not possible. This hypothesis was presented by Pearce (1999) under similar conditions.

The lesions observed, especially the thickening of the intestinal walls, characterized the pathological process as Intestinal Adenomatosis according to the classification system for swine presented by Rowland \& Lawson (1975) and used by several authors (Morés et al. 1985, McOrist et al. 1995, Guedes et al. 2002), with lesions concentrated in the ileum but extending, with less severity, to other portions 
(ileocecal valve and cecum). These findings are similar to those described in other reports on the disease in rabbits (Umemura et al. 1982, Duhamel et al. 1998, Watarai et al. 2004).

Therefore, in a general way, the classical lesion types related to PE found in this study (cryptal cell hyperplasia, hyperchromatism, and pseudostratified arrangement), as well as the different types of inflammatory infiltrates observed, are compatible with those found in Intestinal Adenomatosis in rabbits (Umemura et al. 1982, Duhamel et al. 1998, Schauer et al. 1998).

No report of the occurrence of globular leukocytes in $\mathrm{PE}$, present in large numbers in the lesions studied, was found in the literature; the biological meaning of their presence remains unknown in these rabbits. On the other hand, these cells have been associated with intensification of immune-mediated responses (Finn \& Schwartz 1972), leading to the possibility that they are involved in local defense against the bacterial infectant. We believe that the variation in the amount of goblet cells is associated with different stages of the disease, because animals in the initial and recovery stages may display an increase in the number of these cells; whereas, animals in which the disease is in progression, exhibit a decrease in goblet cell numbers as a significant alteration (Rowland \& Lawson 1975).

Acknowledgements.- The authors thank Dr Prof. Roberto Maurício Carvalho Guedes, Federal University of Minas Gerais (UFMG), for having made available the anti- $L i$ polyclonal antibody used for the imunohistochemistry.

\section{REFERENCES}

Boesen H.T., Jensen T.K., Schmidt A.S., Jensen B.B., Jensen S.M. \& Moller K. 2004. The Influence of diet on Lawsonia intracellularis colonization in pigs upon experimental challenge. Vet. Microbiol. 103:35-44.

Cooper D.M., Swanson D.L. \& Gebhart C.J. 1997. Diagnosis of proliferative enteritis in frozen and formalin-fixed, paraffin-embedded tissues from a hamster, horse, deer and ostrich using a Lawsonia intracellularis-specific multiplex PCR. Vet. Microbiol. 54:47-62.

Duhamel G.E., Klein E.C., Elder R.O. \& Gebhart C.J. 1998. Subclinical proliferative enteropathy in sentinel rabbits associated with Lawsonia intracellularis. J. Comp. Pathol. 35:300-303.

Finn J.P. \& Schwartz L.W. 1972. A neoplasm of globule leukocytes in the intestine of a cat. J. Comp. Pathol. 82:323-328.

Go Y.Y., Lee J.K., Ye J.Y., Lee J.B., Park S.Y., Song C.S., Kim S.K. \& Choi I.S. 2005. Experimental reproduction of proliferative enteropathy and the role of IFNã in protective immunity against Lawsonia intracellularis in mice. J. Vet. Sci. 6(4):357-359.

Guedes R.M., Gebhart C.J., Wilkelman N., Mackie-Nuss R.A., Marsteller T.A. \& Deen J. 2002. Comparison of different methods for diagnosis of porcine proliferative enteropathy. Can. J. Vet. Res. 66:99-107.

Hotchkiss C.E., Shames B., Perkins S.E. \& Fox J.G. 1996. Proliferative enteropathy of rabbits: the intracellular Campylobacter-like organism is closely related to Lawsonia intracellularis. Lab. Animal Sci. 46:623-627.

Jacobson M., GerthLöfstedt M., Holmgren N., Lundeheim N. \& Fellström C. 2005. The prevalences of Brachyspira spp. and Lawsonia intracellularis in Swedish piglet producing herds and wild boar population. J. Vet. Med. Ser.B 52(9):386-391.

Jones G.F., Ward G.E., Murtaugh M.P., Lin G. \& Gebhart C.J. 1993. Enhanced detection of intracellular organism of swine proliferative enteritis, ileal symbiont intracellularis, in feces by polymerase chain reaction. J. Clin. Microbiol. 31(10):2611-2615.
Lemarchand T.X., Tully T.N., Shane S.M. \& Duncan D.E. 1997. Intracellular Campylobacter-like organism associated with rectal prolapse and proliferative enteroproctitis in emus (Dromaius novaehollandiae). Vet. Pathol. 34:152-156.

Love R.N., Love D.N. \& Edwards M.J. 1977. Proliferative haemorrhagic enteropathy in pigs. Vet. Rec. 100(4):65-68.

McOrist S., Maclntyre N., Stokes C.R. \& Lawson G.H.K. 1992. Immunocytological responses in porcine proliferative enteropathies. Infect. Immun. 60:4184-4191.

McOrist S., Jasni S., Mackie R., MacIntyre N., Neef N. \& Lawson G. 1993. Reproduction of porcine proliferative enteropathy with pure cultures of ileal symbiont intracellularis. Infect. Immun. 61(10):4286-4292.

McOrist S., Gebhart C.J., Boid R. \& Barns S.M. 1995. Characterization of Lawsonia-intracellularis gen-nov, sp-nov, the obligately intracellular bacterium of porcine proliferative enteropathy. Int. J. Syst. Bacteriol. 45(4):820-825.

Moon H.W., Cutlip R.C., Amtower W.C. \& Matthews P.J. 1974. Intraepitelial Vibrio associated with acute typhlitis of young rabbits. Vet. Pathol. 11:313-326.

Morés N., Neves D.S., Nogueira R.H.G. \& Guimarães E.B. 1985. Diagnósticos clínico e Anátomo-histológicos de casos espontâneos de Enteropatia Proliferante e Hemorrágica (EPH) em suínos. Arq. Bras. Med. Vet. Zootec. 37(1):29-37.

Pearce G.P. 1997. Interactions between dietary fibre, endo-parasites and Lawsonia intracellularis bacteria in grower-finisher pigs. Vet. Parasitology 87:51-61.

Pearce G.P. 1999. Epidemiology of enteric disease in grower-finisher pigs: a postal survey of pig producers in England. Vet. Rec. 144(13): 338-342.

Rowland A.C. \& Hutchings D.A. 1978. Necrotic enteritis and regional ileitis in pigs at slaughter. Vet. Rec. 103(15):338-339.

Rowland A.C. \& Lawson G.H.K. 1975. Porcine intestinal adenomatosis: a possible relationship with necrotic enteritis, regional ileitis and proliferative haemorrhagic enteropathy. Vet. Rec. 97(10):178-180.

Schauer D.B., McCathey S.N., Daft B.M., Jha S.S., Tatterson L.E., Taylor N.S. \& Fox J.G. 1998. Proliferative Enterocolitis associated with dual infection with enteropathogenic Escherichia coli and Lawsonia intracellularis in rabbits. J. Clin. Microbiol. 36(6):1700-1703.

Segalés J., Fernández-Salguero J.M., Fructuoso G., Quintana J., Rosell J., Pozo J., Arriba M.L., Rubio M. \& Domingo J. 2001. Granulomatous enteritis and lymphadenitis in Iberian pigs naturally infected with Lawsonia intracellularis. Vet. Pathol. 38(3):343-346.

Sonne L., Pescador C.A., Zlotowski P., Bohrer P.V., Moleta E.C., Castagna S.M.F., Bessa M.C. \& Driemeier D. 2003. Mortalidade de coelhos associada à Enteropatia Proliferativa causada por Lawsonia intracellularis no Rio Grande do Sul. Anais XI Encontro Nacional de Patologia Veterinária, Botucatu.

Smith D.G.E. \& Lawson G.H. 2001. Lawsonia intracellularis: getting inside the pathogenesis of proliferative enteropathy. Vet. Microbiol. 82(4):331345.

Stege H., Jensen T.K., Möller K., Baekbo P. \& Jorsal S.E. 2000. Prevalence of intestinal pathogens in Danish finishing pig herds. Prev. Vet. Med. 46(4):279-292.

Tomatová K., Literák I. \& Klimes J. 2003. Lawsonia intracellularis in wild mammals in the Slovak Carpathians. J. Wildl. Dis. 39(2):407-411.

Umemura T., Tsuchitani M., Totsuka M., Narame I. \& Yamachiro S. 1982. Histiocytic enteritis of rabbits. Vet. Pathol. 19:326-328.

Watarai M., Yamato Y., Horiuchi N., Kim S., Omata Y., Shirahata T. \& Furuoka H. 2004. Enzyme-Linked Immunosorbent Assay to Detect Lawsonia intracellularis in rabbits with Proliferative Enteropathy. J. Vet. Med. Sci. 66(6):735-737.

Wuersch K., Huessy D. \& Koch K. 2006. Lawsonia intracellularis Proliferative Enteropathy in a filly. J. Vet. Med. Ser.A 53:17-21. 